Egyptian Journal of Aquatic Biology \& Fisheries

Zoology Department, Faculty of Science,

Ain Shams University, Cairo, Egypt.

ISSN $1110-6131$

Vol. 25(1): 643- 663 (2021)

www.ejabf.journals.ekb.eg

\title{
The Impact of Zeolite on Ammonia Toxicity, Growth Performance and Physiological Status of the Nile Tilapia (Oreochromius niloticus)
}

\section{Adel M. Shalaby ${ }^{1}$, Mohamed k. Khames ${ }^{2}$, Adel Fathy ${ }^{1}$, Amany A. Gharieb ${ }^{1}$, Eman A. Abdel-Hamid ${ }^{* 3}$}

1- Hatchery and Fish Physiology Dept.

2- Fish Nutrition Dept.

3- Limnology Dept.

Central Laboratory for Aquaculture Research, Abbassa, Sharqia, Egypt

*Corresponding author: e_abdelhamid2014@yahoo.com

ARTICLE INFO

Article History:

Received: Oct. 14, 2020

Accepted: Dec. 28, 2020

Online: Feb. 14, 2021

Key words:

Nile tilapia,

Ammonia,

zeolite,

growth,

physiology
ABSTRACT

Environmental pollution adversely affects fish growth and health. Thus, the search for agents that have a protective role against pollutants' toxicity is worthwhile; especially those with the potential natural biological occurrence and no side effects. Hence, an investigation was undertaken to examine the opposing effect of zeolite against ammonia toxicity which induced perturbations in some hematological, biochemical parameters and poor growth in Nile tilapia $(O$. niloticus). Moreover, an evaluation of the efficiency of chelating zeolite to counteract the toxicity of two levels of ammonium chloride (18 and $1.8 \mathrm{mg}$ $\mathrm{NH}_{4} \mathrm{cl} / \mathrm{l}$ ) was conducted. Fingerlings Nile tilapia, with weight ranges from $9.1-9.4$ $\mathrm{g}$, were assigned to five groups with three replicates. The first group was determined as control with zero additions. The 2 nd and the 4 th were exposed to 18 and $1.8 \mathrm{mg} \mathrm{NH} \mathrm{m}_{4} \mathrm{Cl} / \mathrm{l}$, respectively. In addition, the $3^{\text {rd }}$ and the 5 th groups were exposed to the same concentration of ammonium chloride with $6 \mathrm{~g}$ Zeolite $/ 1$, respectively. As result, congruent with an increase in ammonia, a significant decrease was detected in growth performance, feed intake, feed conversion ratio, erythrocyte count $\left(\mathrm{RBC}_{\mathrm{S}}\right)$, hemoglobin content $(\mathrm{HB})$, hematocrit value $(\mathrm{Hct})$ and total protein in fish exposed to doses of ammonia. Moreover, the addition of zeolite enhanced the blood parameter and growth in fish exposed to a low concentration of ammonia, recording values close to those of the control fish. On the other hand, the glucose concentration, alanine aminotransferase activity (ALT), alkaline phosphatase (ALK), total lipid profile and kidney function increased significantly, particularly in fish exposed to the two levels of ammonia toxicity. Whereas, its values in a fish group exposed to a low concentration of ammonia with $6 \mathrm{~g}$ of zeolite became similar to those of the control. Thus, the addition of zeolite to ammonia in a contaminated medium is recommended to reduce ammonia concentration in aquaculture, improve growth performance and physiological function and activities in fish.

\section{INTRODUCTION}

Aquaculture is a fast growing industry, which represents one third of the world fisheries production (Lowther, 2005). In Egypt, the production of fish from aquaculture 
sources is about 70\% (127632 tons) of the total fish production (GAFRD, 2012). The total production of all sources in Egypt reached about one million tons (1.077) in 2012 (FAO, 2014) while, the total fish production of all sources was estimated by two million tons (GAFRD, 2019).

Due to their capabilities to tolerate a wide range of environmental factors and stress conditions, tilapias have been described as one of the most important freshwater fish (El-Sayed, 2006).

Water quality is a critical factor in fish farming particularly in fresh water. Hence, to obtain the optimum production of fresh water fish farming and ensure fish growth and survival, water quality should be monitored to attain optimal conditions that varies with species. The concentration of total ammonia nitrogen (TAN) is the key limiting water quality parameter in aquaculture. In confined or recirculating systems of aquaculture, such as tanks and aquariums, the causes of diseases and fish mortalities are related to the outcome of ammonia from the decomposition of excreta and unfed fish feed (El-Gendy et al., 2015). Owing to its detrimental effect on the growth and health of fish, ammonia nitrogen is the major toxic pollutant in aquaculture system. Ammonia exists in two forms: ionized ammonia $\left(\mathrm{NH}^{+}\right)$and unionized ammonia $\left(\mathrm{NH}_{3}\right)$, while both are commonly expressed as total ammonia. Remarkedly, even at low concentrations, ammonia possesses a toxic impact on fish, and hence, may cause serious problems in aquaculture production (Morrison and Piper, 1988). The probable effects of high concentration of ammonia on the fish species, reared in collapsible and concrete tanks, include damages to tissue, gill and kidney, as well as a reduction in growth (Rodrigues $\boldsymbol{e t}$ al., 2013). The manifestation of these effects depends on the life stage of the fish, the period of exposure, and the tolerance of the species to ammonia concentrations.

Most studies have found that the best feed for optimal fish production in aquaculture is feed rich in protein, the amount of which varies among different fish species recording a percentage of 30 to 60 (Mustapha et al., 2014). The ammonia excreted through the gills and feces is the end product of digesting the present protein in fish feed. The amount of excreted ammonia depends on the percentage of protein present in the feed, the amount of feed in the aquaculture holding tanks and the rate of feeding.

The expansion in aquaculture practices accompanied with the intensification of aquaculture has caused pollution directly linked to the elevated levels of fish stressors, both environmental and physiological. In addition, immune system suppression and disease-causing infections followed by chemical treatments have negatively impacted fish health (Reverter et al., 2014). Aquatic animals excrete ammonia as a product of protein metabolism, the mineralization of feed waste and organic nitrogen metabolism in feces (Avnimelech \& Ritvo, 2003). The main concern regarding excessive nitrogen loads in fish ponds is the transformation of ammonia to the toxic form (Páez-Osuna, 2001). 
Therefore, it is important to remove ammonia from water, and at the meantime improve the water quality of fish farming systems.

However, due to the high management cost of bioreactors in large open marine culture pond systems, options for the safe deposition of treated effluents are very limited. Some natural resin, such as zeolite, is used to remove ammonia from wastewater and clinoptilolite, which is one of the best zeolites in ammonia removal ion exchange process (Farhangi \& Rostami-Charati, 2012). Zeolites are microporous crystalline hydrated aluminosilicates, which have been used in various applications due to their unique physicochemical characteristics such as ion exchange and adsorption-desorption properties (Ghasemi et al., 2016).

Boyd and Tucker (1998) inferred that natural zeolite and activated carbon are typically used as safe agents for ammonia removal from intensively cultured ponds, Zeolite, exhibits poorer ability to remove ammonia from seawater than from freshwater due to the large quantity of cations found in seawater, which lowers the ammonia absorption ability of zeolite. The poor ability to remove ammonia from seawater compared to freshwater is due to the large quantity of cations found in seawater, which lowers the ammonia adsorption ability of zeolite. Shalaby et al. (2018) reported that the addition of zeolite to $\mathrm{Cd}$ contaminated medium enhanced the biochemical parameters in fish, and the enzyme activities returned to be as that of the control group. Furthermore, they added that the addition of zeolite to Cd contaminated medium considerably reduced cadmium absorption and accumulation in gills. Therefore, the present study investigated ammonia effects on the growth performance and some physiological parameters of the Nile tilapia (Oreochromius niloticus), a very common fish species in Egypt and an important food source for human and bioindicator organisms for environmental monitoring. In order to evaluate ammonia effects, an examination of hematological and biochemical parameter exposed to two sublethal ammonia concentrations with or without zeolite was organized. Another successive experiment was conducted to assess the capability of zeolite for a while to absorb ammonia in rearing water and reduce their impact on fish health.

\section{MATERIALS AND METHODS}

The experimental work of this study was carried out in indoor wet Lab at Central Laboratory of Aquaculture Research, Abbassa, Abo-Hammad, Sharqia, Egypt. Nile tilapia " Oreochromius niloticis" with average weight of 9.1-9.4 g/fish were acclimated in laboratory conditions for 2 weeks before the beginning of the experimental work. Fish were distributed in fifteen glass aquaria of about 100-liter capacity and stocked at a rate of 10-fish/ aquarium. The glass aquaria were supplied with dechlorinated tap water, and continuous aeration was adapted by using an air pump and air stones. Average water temperature was maintained at $27 \pm 0.8{ }^{\circ} \mathrm{C}$. The aquaria were divided into 5 groups with three replicates per group. The $1 \mathrm{st}$ 
group was kept as control, 2nd and 4nd groups received 18 and $1.8 \mathrm{mg} / \mathrm{l}$ of ammonium chloride, respectively. Other groups received same doses of $\mathrm{NH}_{4} \mathrm{cl}$, respectively, in addition to $6 \mathrm{~g}$ zeolite $/ \mathrm{l}$ (groups 3,5). The treatments are illustrated in Table (1).

Table 1. Experimental groups and their notation

\begin{tabular}{|ccc|}
\hline Groups & Ammonium chloride (mg/l) & Zeolite (g/l) \\
\hline T1 & - & - \\
\hline T2 & 18 & - \\
\hline T3 & 18 & 6 \\
\hline T4 & 1.8 & - \\
\hline T5 & 1.8 & 6 \\
\hline
\end{tabular}

Fish of the experimental groups were fed on a pelleted fish diet containing $30 \%$ $\mathrm{CP}$ (Table 2) and the diet was fed at a rate of $3 \%$ of live body weight twice daily for 90 days. Semi-dynamic method to remove excreta was used every day by siphoning a portion of water from the aquarium and replacing it by an equal volume of water.

Table 2. Chemical analysis of commercial diet used in the experiment (on dry matter basis)

\begin{tabular}{|cc|}
\hline Items & Percent \\
\hline Dry matter (DM \%) & 93.12 \\
\hline Crud protein (CP \%) & 29.65 \\
\hline Ether extract (EE \%) & 6.23 \\
\hline Crud fiber (CF \%) & 6.67 \\
\hline Ash & 12.12 \\
\hline NFE & 45.33 \\
\hline GE Kcal/100g & 412.7 \\
\hline P / E ratio & 71.84 \\
\hline
\end{tabular}

\section{Water quality measurements}

Water samples were collected weekly at $15 \mathrm{~cm}$ depth from each aquarium. Dissolved oxygen (DO) and water temperature were measured in situ with an oxygen meter (YSI model 58, Yellow Spring Instrument Co., Yellow Springs, OH, USA). Whereas, pH value was measured with a $\mathrm{pH}$ meter (Digital Mini-pH Meter, model 55, Fisher Scientific, Denver, $\mathrm{CO}$, USA). Un-ionized ammonia $\left(\mathrm{NH}_{3}\right.$ ) was determined by measuring ammonium concentration by Hach comparison apparatus following the method reported by APHA (2000). Nitrite $\left(\mathrm{NO}_{2}\right)$ was detected by phenol disulphonic acid method, then by using spectrophotometer (model, WPA Linton Cambridge UK) at wave length of $410 \mathrm{~nm}$, as 
described by APHA (2000). Total Hardness and total alkalinity were measured by methods described by APHA (2000). Salinity and Electrical conductivity (EC) were measured by the salinity-conductivity meter (model YSI Environmental, EC 300). In all treatments, DO concentrations ranged from 4.1 to $4.6 \mathrm{mg} / \mathrm{L}$, and water temperature average was $27 \pm 0.8 \mathrm{C}^{\circ}$, $\mathrm{pH}$ value ranged from 7.2 to 7.6. All the water quality parameters were within the acceptable ranges for fish growth (Boyd, 1984).

\section{Fish growth}

Growth and feed utilization indices were calculated: weight gain (WG), specific growth rate (SGR), food conversion ratio (FCR), feed efficiency (FE) and protein efficiency ratio (PER) using the following formulae: according to Jauncey and Rose (1982)

$\mathrm{WG}=\mathrm{W} 2-\mathrm{W} 1$ Final average weight $(\mathrm{g})-$ initial average weight $(\mathrm{g})$;

$\operatorname{SGR}(\% \mathrm{~d}-1)=100 \times(\ln \mathrm{W} 2-\ln \mathrm{W} 1) / \mathrm{t}$

Where W2 and W1 represent final and initial body weights of fish, respectively, and T is the number of days of the experimental period.I

Relative body weight gain (RBWG) was calculated according to the following equation RBWG $=(w t 2-w t 1) \times 100 / w t 1$

FCR = Dry weight of feed (g) / wet weight gain by fish (g); PER = weight gain by fish (g) / protein intake $(\mathrm{g}), \mathrm{RGR}=$ weight gain/ initial weight, FER=weight gain / feed intake $* 100$ and $\mathrm{PPV}=$ relative protein/ protein intake*100

Where protein intake $(\mathrm{g})=$ Protein $(\%)$ in feed $\times$ total weight $(\mathrm{g})$ of diet consumed $/ 100$ Physiological measurements

At the end of the experimental period, 6 fish from each treatment and control group were taken for physiological investigations. Fish were not fed for 24 hours prior to blood sampling. Blood samples were taken from the caudal vein of non anaesthetized fish by sterile syringe containing EDTA as an anticoagulant. The detection of Erythrocyte count was assigned according to Dacie and Lewis (1984), while hemoglobin content was determined according to Van kampen (1961) and hematocrit value was estimated according to Britton (1963).

Plasma was obtained by blood centrifugation at $3000 \mathrm{rpm}$ for $15 \mathrm{~min}$, and the nonhemolyzed plasma was stored in a deep freezer at-20 ${ }^{\circ}$ till analysis. Glucose concentration was measured according to Trinder (1969). Plasma protein content was determined by Biuret method using Boehring Mannheium kits described by Wotton (1964). Total lipids were determined colorimetrically using kits supplied by El Nasr Pharmaceutical Chemical Co. according to Joseph et al. (1972). Aspartate aminotransferase (AST) and alanine aminotransferase (ALT) were determined colorimetrically using kits supplied by Diamond Diagnostics according to Reitman and Frankel (1957).

\section{Proximate chemical analyses}

The proximate chemical analyses of whole-fish bodies were carried out according to the standard methods of AOAC (1990) for moisture, crude protein, total lipids, and total 
ash. Moisture content was estimated by drying the samples at $85^{\circ} \mathrm{c}$ in a heat-oven (GCA, model 18EM, Precision Scientific group, Chicago, Illinois, USA) for $48 \mathrm{~h}$. Nitrogen content was measured using a microkjeldahl apparatus (Labconco, Labconco Corporation, Kansas, Missouri, USA), and crude protein was estimated by multiplying nitrogen content by 6.25 . Lipid content was determined by ether extraction in multi-unit extraction Soxhlet apparatus (Lab-Line Instruments, Inc., Melrose Park, Illinois, USA) for $16 \mathrm{~h}$. Total ash was determined by combusting dry samples in a muffle furnace (Thermolyne corporation, Dubuque, Lowa, USA) at $550^{\circ} \mathrm{c}$ for $6 \mathrm{~h}$.

\section{Statistical analysis}

The obtained data were subjected to analysis of variance according to Snedecor and Cochran (1982). Differences between means were done at the 5\% probability level, using Duncan's new multiple range test (Duncan, 1955).

\section{RESULTS}

\section{Water quality parameters}

All water quality parameters that were analyzed are represented in Table 3. Controlling water temperature in the experiment ensured that the temperature was consistent in all treatments. Dissolved oxygen level was lower in the two doses of ammonia treatments as compared to control, it remained above $4.0 \mathrm{mg} / \mathrm{l}$ in both treatments, which was the level suggested so as not to restrict the growth performance of fish. In addition, other water parameters, including $\mathrm{pH}$, alkalinity, Nitrite $\left(\mathrm{NO}_{2}\right)$ and $\mathrm{EC}$ were significantly different between the treatments when compared to the control group. These differences occurred due to being exposed to ammonia concentration with or without zeolite. The salinity concentration showed no variation among treatments.

Table 3. The water quality in experimental of $O$. niloticus after exposed to ammonia toxicity with or without zeolite

\begin{tabular}{|c|c|c|c|c|c|c|c|c|c|c|}
\hline $\begin{array}{c}\text { Rarameters } \\
\text { Treatments }\end{array}$ & $\mathrm{pH}$ & $\mathrm{DO}$ & $\begin{array}{c}\text { Total } \\
\text { ammonia }\end{array}$ & $\mathrm{NH}_{3}$ & $\begin{array}{c}\text { Total } \\
\text { alkalinity }\end{array}$ & $\begin{array}{c}\text { Total } \\
\text { hardness }\end{array}$ & $\mathrm{NO}_{2}$ & Temp. ${ }^{\circ} \mathrm{C}$ & $\begin{array}{c}\mathrm{EC} \\
(\mathrm{mS} / \mathrm{cm})\end{array}$ & Salinity \\
\hline \multirow[t]{2}{*}{ T1(control) } & $7.51 \pm$ & $5.23 \pm$ & $0.44 \pm$ & $0.03 \pm$ & $142.00 \pm$ & $141.60 \pm$ & $1.43 \pm$ & $23.44 \pm$ & $457.20 \pm$ & 0.26 \\
\hline & $0.13^{c}$ & $0.19^{a}$ & $0.02^{c}$ & $0.012^{c}$ & $3.74^{\mathrm{bc}}$ & $10.78^{a}$ & $0.51^{\mathrm{ab}}$ & $1.29^{a}$ & $9.28^{b}$ & $0.01^{\mathrm{a}}$ \\
\hline $\mathrm{T} 2$ (18mg & 9.34 & $5.02 \pm$ & $2.55 \pm$ & $1.76 \pm$ & $149.60 \pm$ & $126.00 \pm$ & $2.31 \pm$ & $23.44 \pm$ & $515.00 \pm$ & $0.33 \pm$ \\
\hline $\left.\mathrm{NH}_{4} \mathrm{Cl} / \mathrm{l}\right)$ & $0.16^{\mathrm{a}}$ & $0.11^{\mathrm{a}}$ & $0.07^{a}$ & $0.23^{a}$ & $2.04^{a}$ & $2.97 \mathrm{abc}$ & $0.19^{a}$ & $1.29^{a}$ & $23.69^{a}$ & $0.02^{\mathrm{a}}$ \\
\hline T3(18mg & $8.72 \pm$ & 5.44 & $1.48 \pm$ & 0.46 & $133.60 \pm$ & $128.80 \pm$ & $1.19 \pm$ & $23.44 \pm$ & $480.20 \pm$ & $0.26 \pm$ \\
\hline $\left.\mathrm{NH}_{4} \mathrm{Cl}+6 \mathrm{~g} \mathrm{z} / \mathrm{l}\right)$ & $0.19^{b}$ & $0.25^{\mathrm{a}}$ & $0.04^{\mathrm{b}}$ & $0.12^{\mathrm{b}}$ & $3.08^{c}$ & $2.42^{\mathrm{abc}}$ & $0.23^{\mathrm{ab}}$ & $1.29^{a}$ & $10.25^{\mathrm{ab}}$ & $0.004^{a}$ \\
\hline \multirow[t]{2}{*}{$\mathrm{T} 4\left(1.8 \mathrm{mg} \mathrm{NH}_{4} \mathrm{Cl} / \mathrm{l}\right)$} & $7.89 \pm$ & $5.05 \pm$ & $1.49 \pm$ & $0.10 \pm$ & $173.60 \pm$ & $115.60 \pm$ & $1.53 \pm$ & $23.44 \pm$ & $478.00 \pm$ & $0.28 \pm$ \\
\hline & $0.16^{c}$ & $0.10^{\mathrm{a}}$ & $0.06^{\mathrm{b}}$ & $0.04^{c}$ & $7.13^{a}$ & $1.47^{\mathrm{bc}}$ & $0.34^{\mathrm{ab}}$ & $1.29^{a}$ & $19.24^{\mathrm{ab}}$ & $0.08^{\mathrm{a}}$ \\
\hline T5 (1.8 mg & $7.47 \pm$ & $5.16 \pm$ & $0.46 \pm$ & $0 \quad .01 \pm$ & $144.00 \pm$ & $111.20 \pm$ & $0.92 \pm$ & $23.44 \pm$ & $495.20 \pm$ & $0.31 \pm$ \\
\hline $\left.\mathrm{NH}_{4} \mathrm{Cl}+6 \mathrm{~g} \mathrm{z} / \mathrm{l}\right)$ & $0.15^{c}$ & $0.22^{\mathrm{a}}$ & $0.04^{c}$ & $0.003^{c}$ & $5.09 \mathrm{bc}$ & $2.15^{c}$ & $0.08^{c}$ & $1.29 \mathrm{a}$ & $7.94^{\mathrm{ab}}$ & $0.02^{\mathrm{a}}$ \\
\hline
\end{tabular}

The same letter in the same column is not significantly different at $\mathrm{P}<0.05$. 


\section{Growth performance}

Table 4. shows the growth performance of Nile tilapia fingerlings during the experiment. The mean values of weight gain (WG), specific growth rate (SGR) and Relative growth rate (RGR) of Nile tilapia fingerlings were $(16.87 \& 17.16$,WG, $1.72 \& 1.74$, SGR and $1.81 \& 1.84$, RGR) for treatments 2 and 4, respectively. Significant differences were detected within the control group $(19.14,1.87 \& 2.068$, respectively).

Table 4. The growth performance (weight gain, specific growth rate and relative growth rate) in

$O$. niloticus after being exposed to ammonia toxicity with or without zeolite

\begin{tabular}{|c|c|c|c|c|c|}
\hline & \multicolumn{2}{|c|}{ High doses } & \multicolumn{2}{|c|}{ Low doses } \\
\hline \multirow{3}{*}{ Preatments } & \multirow{3}{*}{$\begin{array}{c}\mathrm{T} 1 \\
\text { Control }\end{array}$} & $\mathrm{T} 2$ & T3 & $\mathrm{T} 4$ & T5 \\
\hline & & $18 \mathrm{mg} \mathrm{NH}_{4} \mathrm{Cl} / 1$ & $18 \mathrm{mg} \mathrm{NH}_{4} \mathrm{Cl}$ & $1.8 \mathrm{mg}$ & $1.8 \mathrm{mg} \mathrm{NH}_{4} \mathrm{Cl}$ \\
\hline & & & $+6 \mathrm{~g} \mathrm{z} / 1$ & $\mathrm{NH}_{4} \mathrm{Cl} / \mathrm{l}$ & $+6 \mathrm{~g} \mathrm{z} / 1$ \\
\hline Initial & $9.27 \pm$ & $9.34 \pm$ & $9.22 \pm$ & $9.31 \pm$ & $9.17 \pm$ \\
\hline weight & $0.032^{\mathrm{a}}$ & $0.015^{\mathrm{a}}$ & $0.043^{\mathrm{a}}$ & $0.079^{a}$ & $0.052^{\mathrm{a}}$ \\
\hline \multirow[t]{2}{*}{ Final weight } & $28.41 \pm$ & $26.18 \pm$ & $28.20 \pm$ & $26.50 \pm$ & $31.83 \pm$ \\
\hline & $0.087 \mathrm{~b}$ & $0.017 \mathrm{~d}$ & $0.087 \mathrm{~b}$ & $0.012^{c}$ & $0.060^{a}$ \\
\hline \multirow[t]{2}{*}{ Weight gain } & $19.14 \pm$ & $16.87 \pm$ & $18.98 \pm$ & $17.16 \pm$ & $22.67 \pm$ \\
\hline & $0.063^{b}$ & $0.062^{c}$ & $0.104^{\mathrm{b}}$ & $0.101^{c}$ & $0.0 .13^{a}$ \\
\hline \multirow{2}{*}{$\begin{array}{l}\text { Daily weight } \\
\text { gain }\end{array}$} & $0.319 \pm$ & $0.281 \pm$ & $0.316 \pm$ & $0.286 \pm$ & $0.378 \pm$ \\
\hline & $0.001^{\mathrm{b}}$ & $0.001^{\mathrm{d}}$ & $0.002^{\mathrm{b}}$ & $0.002^{c}$ & $0.0 .001^{\mathrm{a}}$ \\
\hline \multirow{2}{*}{$\begin{array}{l}\text { Specific } \\
\text { growth rate }\end{array}$} & $1.87 \pm$ & $1.72 \pm$ & $1.86 \pm$ & $1.74 \pm$ & $2.07 \pm$ \\
\hline & $0.003^{\mathrm{b}}$ & $0.013^{c}$ & $0.01^{\mathrm{b}}$ & $0.005^{c}$ & $0.006^{\mathrm{a}}$ \\
\hline \multirow{2}{*}{$\begin{array}{l}\text { Relative } \\
\text { growth rate }\end{array}$} & $2.068 \pm$ & $1.81 \pm$ & $2.06 \pm$ & $1.84 \pm$ & $2.47 \pm$ \\
\hline & $0.006^{\mathrm{b}}$ & $0.022^{c}$ & $0.018^{b}$ & $0.008^{c}$ & $0.013^{a}$ \\
\hline
\end{tabular}

The same letter in the same row is not significantly different at $\mathrm{P}<0.05$.

On the other hand, these values increased significantly to (22.67 for W.G, 2.07 for SGR and 2.47 for RGR, respectively) in Nile tilapia exposed to low doses of ammonia $(1.8 \mathrm{mg} / \mathrm{L})$ with $6 \mathrm{~g}$ zeolite/l when compared to the control group. These results illustrate that the addition of zeolite has an adversely effect on ammonia concentration. It is noticed that zeolite addition significantly improves fish performance represented by final weight, weight gain, SGR and relative growth rate over those of the control group (T1 Vis T5).

As seen in Table 5. ammonia concentration significantly affected feed conversion ratio (FCR) of fish exposed to $18 \mathrm{mg} \mathrm{NH}_{4}$ and $1.8 \mathrm{mg} \mathrm{NH}_{4} / \mathrm{l}$. The zeolite-exposed fish marked higher value of FCR and recorded the same high value by increasing ammonia shown in T3 groups of fish. Notedly, FCR decreased with a significant decline at $1.8 \mathrm{mg}$. with $6 \mathrm{~g}$ zeolite/l of ammonium chloride in the fourth group (with pre-exposure to zeolite $)(\mathrm{P}<0.01)$. 
Table 5. Feed intake (FI), feed conversation ratio (FCR), feed efficacy ratio (FER), protein efficacy ratio (PER), protein valuation (PPV) and (E.U) in O. niloticus after exposed to ammonia toxicity with or without zeolite

\begin{tabular}{|c|c|c|c|c|c|}
\hline \multirow{2}{*}{ Treatments } & \multirow{2}{*}{$\begin{array}{c}\text { T1 } \\
\text { Control }\end{array}$} & \multicolumn{2}{|c|}{ High doses } & \multicolumn{2}{|c|}{ Low doses } \\
\hline & & $\mathrm{T} 2$ & T3 & $\mathrm{T} 4$ & $\mathrm{~T} 5$ \\
\hline & & $18 \mathrm{mg} \mathrm{NH}_{4} \mathrm{Cl} / \mathrm{l}$ & $18 \mathrm{mg} \mathrm{NH}_{4} \mathrm{Cl}$ & $1.8 \mathrm{mg}$ & $1.8 \mathrm{mg} \mathrm{NH}_{4} \mathrm{Cl}$ \\
\hline Parameters & & & $+6 \mathrm{~g} \mathrm{z} / 1$ & $\mathrm{NH}_{4} \mathrm{Cl} / \mathrm{l}$ & $+6 \mathrm{~g} \mathrm{z} / 1$ \\
\hline \multirow[t]{2}{*}{ FI } & $35.42 \pm$ & $43.07 \pm$ & $38.67 \pm$ & $39.85 \pm$ & $33.74 \pm$ \\
\hline & 0.5 & $1.171^{\mathrm{a}}$ & $0.392^{\mathrm{b}}$ & $0.519^{b}$ & $0.367^{d}$ \\
\hline \multirow[t]{2}{*}{ FCR } & $1.85 \pm$ & $2.25 \pm$ & $2.00 \pm$ & $2.10 \pm$ & $1.90 \pm$ \\
\hline & $0.023^{\mathrm{d}}$ & $0.015^{\mathrm{a}}$ & $0.029^{c}$ & $0.017^{b}$ & $0.029^{d}$ \\
\hline \multirow[t]{2}{*}{ FER } & $54.07 \pm$ & $44.38 \pm$ & $50.02 \pm$ & $47.63 \pm$ & $52.66 \pm$ \\
\hline & $0.675^{a}$ & $0.286^{\mathrm{d}}$ & $0.722^{\mathrm{b}}$ & $0.393^{c}$ & $0.800^{\mathrm{a}}$ \\
\hline \multirow[t]{2}{*}{ PER } & $1.82 \pm$ & $1.50 \pm$ & $1.69 \pm$ & $1.61 \pm$ & $1.78 \pm$ \\
\hline & $0.023^{\mathrm{a}}$ & $0.010^{\mathrm{d}}$ & $0.24^{\mathrm{b}}$ & $0.013^{c}$ & $0.027^{a}$ \\
\hline \multirow[t]{2}{*}{ PPV } & $26.21 \pm$ & $13.24 \pm$ & $20.13 \pm$ & $17.95 \pm$ & $21.59 \pm$ \\
\hline & $0.962^{a}$ & $0.27^{\mathrm{d}}$ & $0.05^{\mathrm{b}}$ & $0.24^{c}$ & $0.19^{\mathrm{b}}$ \\
\hline \multirow[t]{2}{*}{ EU } & $21.07 \pm$ & $11.46 \pm$ & $16.35 \pm$ & $14.68 \pm$ & $17.12 \pm$ \\
\hline & $0.666^{a}$ & $0.158^{\mathrm{d}}$ & $0.049^{b}$ & $0.181^{c}$ & $0.192^{b}$ \\
\hline
\end{tabular}

The same letter in the same row is not significantly different at $\mathrm{P}<0.05$.

Moreover, by increasing ammonia concentrations, FCR increased so that less value of FCR with significant estimation was observed in zeolite treated fish (This was also obvious from comparing $\mathrm{T} 1, \mathrm{~T} 2$ and $\mathrm{T} 4$, respectively) $(\mathrm{P}<0.01)$. The minimum value of FCR $(1.9 \pm 0.029)$ was achieved in T5, while T2 recorded the highest value $(2.25 \pm 0.015)$. This fact led to significant differences between $\mathrm{T} 2$ and $\mathrm{T} 3$ and also T4 and T5 treatments $(\mathrm{P}<0.01)$.

Results in Table 6. show that dry matter, protein content and total lipids in fish body was significant lower in fish exposed to ammonia toxicity with increasing of concentration. Addition of zeolite to ammonia treated group was an enhancement of these parameters in fish exposed to low concentrations of zeolite only as compared to the control group. Contrarily, the ash content was significantly higher (20.41 and $19.66 \%, \mathrm{P}<0.05)$ in fish exposed to high and low ammonia concentrations, respectively as compared the control $(17.04 \%)$. 
Table 6. Body composition of Nile tilapia after exposed to ammonia with or without zeolite

\begin{tabular}{|lcccc|}
\hline \multicolumn{1}{c}{ Parameters } & DM & CP & EE & Ash \\
\hline Treatments & & & & \\
\hline \multirow{2}{*}{ Ttart } & $23.54^{\mathrm{e}}$ & $57.85^{\mathrm{f}}$ & $19.15^{\mathrm{f}}$ & $23.13^{\mathrm{a}}$ \\
& \pm 0.023 & \pm 0.026 & \pm 0.046 & \pm 0.035 \\
\hline \multirow{2}{*}{$\mathrm{T} 2\left(18 \mathrm{mg} \mathrm{NH}_{4} \mathrm{Cl} / \mathrm{l}\right)$} & $27.35^{\mathrm{a}}$ & $59.58^{\mathrm{a}}$ & $23.11^{\mathrm{a}}$ & $17.04^{\mathrm{f}}$ \\
& \pm 0.029 & \pm 0.015 & \pm 0.035 & \pm 0.020 \\
\hline T3 $\left(18 \mathrm{mg} \mathrm{NH}_{4} \mathrm{Cl}+6 \mathrm{~g}\right.$ & $26.12^{\mathrm{c}}$ & $57.94^{\mathrm{e}}$ & $17.48^{\mathrm{b}}$ & $20.41^{\mathrm{b}}$ \\
$\mathrm{z} / \mathrm{l})$ & \pm 0.072 & \pm 0.006 & \pm 0.003 & \pm 0.013 \\
\hline \multirow{2}{*}{$\mathrm{T} 4\left(1.8 \mathrm{mg} \mathrm{NH}_{4} \mathrm{Cl} / \mathrm{l}\right)$} & $26.85^{\mathrm{bc}}$ & $58.62^{\mathrm{c}}$ & $19.22^{\mathrm{c}}$ & $19.22^{\mathrm{d}}$ \\
& \pm 0.006 & \pm 0.009 & \pm 0.022 & \pm 0.022 \\
\hline T5 $(1.8 \mathrm{mg} \mathrm{NH} 4 \mathrm{Cl}+6 \mathrm{~g}$ & $26.75^{\mathrm{bc}}$ & $58.44^{\mathrm{dc}}$ & $19.66^{\mathrm{d}}$ & $19.66^{\mathrm{c}}$ \\
$\mathrm{z} / \mathrm{l})$ & \pm 0.029 & \pm 0009 & \pm 0.018 & \pm 0.018 \\
\hline
\end{tabular}

The same letter in the same column is not significantly different at $\mathrm{P}<0.05$

Table 7. shows a decrease in erythrocyte count in fish groups treated with high concentrations of ammonia with and without zeolite. Although increasing ammonia levels led to erythrocyte falls in both groups, it was higher in fish exposed to zeolite compared to control group $(77.60 \pm 6.852, \mathrm{mg} / \mathrm{dl})$. The addition of zeolite to low doses ammonia caused a recovery of the glucose concentration in the fish blood, the same as the control group.

Table 7. The erythrocyte count $\left(\mathrm{RBC}_{\mathrm{s}}\right)$, hemoglobin content $(\mathrm{HB})$ and hematocrit value (Hct) in blood of Nile tilapia (O. niloticus) after exposed to the ammonia with or without zeolite

\begin{tabular}{|c|c|c|c|c|c|}
\hline Treatments & & & oses & & doses \\
\hline & $\mathrm{T} 1$ & $\mathrm{~T} 2$ & T3 & $\mathrm{T} 4$ & T5 \\
\hline & Control & $18 \mathrm{mg}$ & $18 \mathrm{mg} \mathrm{NH}_{4} \mathrm{Cl}$ & $1.8 \mathrm{mg}$ & $1.8 \mathrm{mg} \mathrm{NH}_{4} \mathrm{Cl}$ \\
\hline Parameters & & $\mathrm{NH}_{4} \mathrm{Cl} / \mathrm{l}$ & $+6 \mathrm{~g} \mathrm{z} / 1$ & $\mathrm{NH}_{4} \mathrm{Cl} / \mathrm{l}$ & $+6 \mathrm{~g} z / 1$ \\
\hline Erythrocyte count & 1.43 & 1.19 & 1.34 & 1.32 & 1.44 \\
\hline$\left(\mathrm{C} / \mathrm{mm}^{3}\right)$ & $\pm 0.11^{\mathrm{a} 3}$ & $\pm 0.006^{c}$ & $\pm 0.108^{a}$ & $\pm 0.008^{\mathrm{a}}$ & $\pm 0.01^{\text {a }}$ \\
\hline Hemoglobin content & 11.17 & 6.57 & 7.97 & 7.05 & 11.03 \\
\hline$(\mathrm{g} / \mathrm{dl})$ & \pm 0.629 a & $\pm 0.390^{c}$ & $\pm 0.295^{b}$ & $\pm 0.873^{\mathrm{b}}$ & $\pm 0.335^{\mathrm{a}}$ \\
\hline Hematocrite (\%) & 29.37 & 17.36 & 23.31 & 18.03 & 27.57 \\
\hline & $\pm 0.43^{a}$ & $\pm 1.98^{\mathrm{d}}$ & $\pm 2.01^{\mathrm{b}}$ & $\pm 0.65^{\mathrm{d}}$ & $\pm 3.01^{\mathrm{a}}$ \\
\hline
\end{tabular}

The same letter in the same row is not significantly different at $\mathrm{P}<0.05$.

In addition, the number of RBCs declined by adding ammonia in water, especially in the groups without zeolite. Meanwhile, those fish which were treated with zeolite showed a higher number of RBCs (Table 6). Moreover, a decrease in hemoglobin level was 
detected congruent with the increase of ammonia concentration. This resulted in significant differences between fish with and without exposure to zeolite $(\mathrm{P}<0.05$, Table 6). Higher hemoglobin amount was seen in the fish exposed to low dose of ammonia with zeolite identical to that in the control group. Also, the hematocrite value in blood fish decreased significantly with increasing of ammonia. Addition of zeolite with low dose of ammonia improved the level of hematocrite value identical to the control group.

The plasma protein content showed a significant lower decrease $(4.68 \pm 0.298$ and $5.17 \pm 0.186 \mathrm{~g} / \mathrm{dl}, \mathrm{P}<0.01)$ in fish exposed to high and low doses of ammonia respectively, when compared to the control group $(6.52 \pm 0.485, \mathrm{~g} / \mathrm{dl})$. On the other hand, the addition of zeolite to low ammonia concentraion, caused nonsignificant variations (5.54 $\pm 0.4,07, \mathrm{~g} / \mathrm{dl})$ when compared to the control group. It was illustrated that the addition of zeolite improve the total protein in blood more than that treated with ammonia alone (Table 8). Data in Table 8 show significant increase in plasma glucose concentration in fish exposed to doses of ammonia alone and high doses of ammonia with zeolite $(140.78 \pm 9.60,135.84 \pm 2.256$ and $108.1 \pm 1 \mathrm{mg} / \mathrm{dl}$, respectively, when compared to the control.

Table 8. The changes of total protein and glucose concentration in plasma of blood Nile tilapia (O. niloticus) after exposed to ammonia toxicity with or without zeolite

\begin{tabular}{|c|c|c|c|c|c|}
\hline \multirow[t]{3}{*}{ Tre } & \multirow[b]{2}{*}{$\mathrm{T} 1$} & \multicolumn{2}{|c|}{ High doses } & \multicolumn{2}{|c|}{ Low doses } \\
\hline & & $\mathrm{T} 2$ & T3 & $\mathrm{T} 4$ & T5 \\
\hline & Control & $\begin{array}{c}18 \mathrm{mg} \\
\mathrm{NH}_{4} \mathrm{Cl} / \mathrm{l}\end{array}$ & $\begin{array}{c}18 \mathrm{mg} \mathrm{NH}_{4} \mathrm{Cl} \\
+6 \mathrm{~g} \mathrm{z} / 1\end{array}$ & $\begin{array}{c}1.8 \mathrm{mg} \\
\mathrm{NH}_{4} \mathrm{Cl} / \mathrm{l}\end{array}$ & $\begin{array}{c}1.8 \mathrm{mg} \mathrm{NH}_{4} \mathrm{Cl} \\
+6 \mathrm{~g} \mathrm{z} / 1\end{array}$ \\
\hline Protein $(\mathrm{g} / \mathrm{dl})$ & 6.52 & 4.68 & 5.21 & 5.17 & 5.54 \\
\hline & $\pm 0.485^{a}$ & $\pm 0.298^{b}$ & $\pm 0.257 \mathrm{~b}$ & $\pm 0.186^{b}$ & $\pm 0.407 \mathrm{ab}$ \\
\hline Glucose (mg/dl) & 77.60 & 140.87 & 108.10 & 135.84 & 81.067 \\
\hline & $\pm 6.852^{c}$ & $\pm 9.60^{a}$ & $\pm 1.58^{c}$ & $\pm 2.256^{a}$ & $\pm 4.47^{c}$ \\
\hline
\end{tabular}

The same letter in the same row is not significantly different at $\mathrm{P}<0.05$.

The ALT activities in plasma of blood Nile tilapia were significantly increased with the increase of ammonia doses, whereas, those values decreased significantly in fish exposed to ammonia with $6 \mathrm{~g}$ of zeolite when compared to the two doses of ammonia toxicity. Similarly, the alkaline phosphatase (ALP) increased significantly in depended dose of ammonia toxicity. Its values decreased significantly in group of ammonia treated with zeolite compared to the control group (Table 9). 
Table 9. The enzymatic activities of alanine amino transferase (ALT) and alkaline phosphatase (ALP) in plasma of Nile tilapia blood (O. niloticus) after exposed to ammonia toxicity with or without zeolite

\begin{tabular}{|lccccc|}
\hline & & \multicolumn{2}{c}{ High dose } & \multicolumn{2}{c|}{ Low dose } \\
\cline { 3 - 6 } & Treatments & $\mathrm{T} 2$ & $\mathrm{~T} 3$ & $\mathrm{~T} 4$ & $\mathrm{~T} 5$ \\
Parameters & Control & $18 \mathrm{mg}$ & $18 \mathrm{mg} \mathrm{NH} \mathrm{Cl}_{4}$ & $1.8 \mathrm{mg}$ & $1.8 \mathrm{mg} \mathrm{NH} \mathrm{Cl}_{4}$ \\
& & $\mathrm{NH}_{4} \mathrm{Cl} / \mathrm{l}$ & $+6 \mathrm{~g} \mathrm{z} / 1$ & $\mathrm{NH}_{4} \mathrm{Cl} / 1$ & $+6 \mathrm{~g} \mathrm{z} / 1$ \\
\hline ALT( IU/l) & $13.57 \pm$ & $57.03 \pm$ & $26.09 \pm$ & $33.23 \pm$ & $23.71 \pm$ \\
& $1.12^{\mathrm{d}}$ & $3.8^{\mathrm{a}}$ & $1.17^{\mathrm{c}}$ & $0.96^{\mathrm{b}}$ & $1.54^{\mathrm{c}}$ \\
\hline ALP (IU/l) & $77.10 \pm$ & $144.90 \pm$ & $36.27 \pm$ & $81.70 \pm$ & $27.450 \pm$ \\
& $0.730^{\mathrm{b}}$ & $8.89^{\mathrm{a}}$ & $2.622^{\mathrm{c}}$ & $7.266^{\mathrm{b}}$ & $1.607^{\mathrm{c}}$ \\
\hline
\end{tabular}

The same letter in the same row is not significantly different at $\mathrm{P}<0.05$.

The mean values of plasma total lipids of Nile tilapia exposed to two doses of ammonia alone and ammonia with zeolite for 90 days are shown in table 10 . It can be observed that fish exposed to dose of ammonia showed a significant increase compared to the control. The total lipids in fish exposed to ammonia with zeolite were similar to those lipids in plasma of the control fish. Similarly, the total cholesterol levels in plasma of Nile tilapia, exposed to high and low dose of ammonia, increased significantly ( $106.77 \pm$ 8.575 and $106.11 \pm 3.998 \mathrm{mg} / \mathrm{dl}$, respectively) when compared to the control group (75.60 $\pm 5.603 \mathrm{mg} / \mathrm{dl})$.

Table 10. The changes of total lipids profiles (total lipids, Cholesterol, Triglyceride and

HDL in plasma of blood Nile tilapia (O. niloticus) after exposed to ammonia toxicity with or without zeolite.

\begin{tabular}{|c|c|c|c|c|c|}
\hline \multirow[t]{2}{*}{ nents } & \multirow[b]{2}{*}{ T1 } & \multicolumn{2}{|c|}{ High doses } & \multicolumn{2}{|c|}{ Low doses } \\
\hline & & $\mathrm{T} 2$ & T3 & $\mathrm{T} 4$ & $\mathrm{~T} 5$ \\
\hline Parametess & Control & $18 \mathrm{mg}$ & $18 \mathrm{mg} \mathrm{NH}_{4} \mathrm{Cl}$ & $1.8 \mathrm{mg}$ & $1.8 \mathrm{mg} \mathrm{NH}_{4} \mathrm{Cl}$ \\
\hline & & $\mathrm{NH}_{4} \mathrm{Cl} / \mathrm{l}$ & $+6 \mathrm{~g} \mathrm{z} / 1$ & $\mathrm{NH}_{4} \mathrm{Cl} / 1$ & $+6 g \mathrm{z} / 1$ \\
\hline Total lipids & $112.9 \pm$ & 903.22 & $114.53 \pm$ & 386.38 & 87.93 \\
\hline$(\mathrm{mg} / \mathrm{dl})$ & $1.652^{c}$ & \pm 16.37 a & $5.386 \mathrm{c}^{\mathrm{c}}$ & $\pm 23.86^{b}$ & $\pm 4.318^{\mathrm{c}}$ \\
\hline Cholesterol & 75.60 & 106.77 & 71.503 & 106.14 & 46.89 \\
\hline$(\mathrm{mg} / \mathrm{dl})$ & $\pm 5.603^{b}$ & $\pm 8.575^{a}$ & $\pm 2.012^{b}$ & $\pm 3.998^{\text {a }}$ & $\pm 1.746^{c}$ \\
\hline Triglyceride & 110.85 & 168.30 & 131.57 & 157.15 & 113.27 \\
\hline$(\mathrm{mg} / \mathrm{dl})$ & $\pm 0.597 \mathrm{c}$ & $\pm 3.66^{\mathrm{a}}$ & $\pm 1.918^{\mathrm{ab}}$ & $\pm 1.87^{\mathrm{b}}$ & $\pm 4.85^{\mathrm{c}}$ \\
\hline HDL (mg/l) & $369.87 \pm$ & $505.57 \pm$ & $485.20 \pm$ & $492.00 \pm$ & $357.07 \pm$ \\
\hline & $14.191^{c}$ & $21.26^{\mathrm{a}}$ & 19.077ab & $4.820^{\mathrm{ab}}$ & $6.938^{c}$ \\
\hline
\end{tabular}

The same letter in the same row is not significantly different at $\mathrm{P}<0.05$.

The addition of zeolite with ammonia toxicity improved the health of fish and reduced cholesterol levels $(71.503 \pm 2.012$ and $46.89 \pm 1.74 \mathrm{mg} / \mathrm{dl}$ at high and low doses, respectively) similar to that in the control group $(75.6 \pm 5.603 \mathrm{mg} / \mathrm{dl})$. As shown in Table

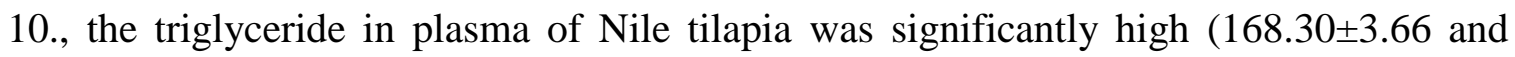


157.15 \pm 1.87 ) in both fish group treated with higher and lower levels of ammonium. The addition of zeolite to low doses of ammonia could counteract with the increase, similar as control, but did not decrease the triglyceride level back to normal value in (T3). Identically, the HDL in plasma in Nile tilapia blood was highly significant after being exposed to two doses of ammonium alone, as compared to the control group. However, with the ammonia plus zeolite treatment there was no marked difference from the control value (Table 10).

The plasma uric acid concentration showed higher significant values $(3.48 \pm 0.295$, $2.63 \pm 0.389,3.29 \pm 126$ and $2.97 \pm 0.133 \mathrm{mg} / \mathrm{dl}, \mathrm{P}<0.01)$ in fish exposed to all doses of ammonia with zeolite (T2, T3, T4 and T5 respectively), as compared to the control group $(1.87 \pm 0.091 \mathrm{mg} / \mathrm{dl})$. Similarly, the creatnine concentration in plasma of Nile tilapia blood was highly significant after exposed to high doses of ammonia alone (12.24 0.343 $\mathrm{mg} / \mathrm{dl}, \mathrm{P}<0.01$ at T2) when compared the control one $(0.59 \pm 0.25 \mathrm{mg} / \mathrm{dl})$ in Table 11.

Table 11. The changes of uric acid and creatnine in plasma of Nile tilapia blood $(O$.

niloticus) after exposed to ammonia toxicity with or without zeolite.

\begin{tabular}{|c|c|c|c|c|c|}
\hline \multirow[t]{3}{*}{$\mathrm{Tr}$} & \multirow[b]{2}{*}{$\mathrm{T} 1$} & \multicolumn{2}{|c|}{ High dose } & \multicolumn{2}{|c|}{ Low dose } \\
\hline & & $\mathrm{T} 2$ & T3 & $\mathrm{T} 4$ & T5 \\
\hline & Control & $18 \mathrm{mg}$ & $18 \mathrm{mg} \mathrm{NH}_{4} \mathrm{Cl}$ & $1.8 \mathrm{mg}$ & $1.8 \mathrm{mg} \mathrm{NH}_{4} \mathrm{Cl}$ \\
\hline Parameters & & $\mathrm{NH}_{4} \mathrm{Cl} / \mathrm{l}$ & $+6 \mathrm{~g} \mathrm{z} / 1$ & $\mathrm{NH}_{4} \mathrm{Cl} / \mathrm{l}$ & $+6 \mathrm{~g} \mathrm{z} / 1$ \\
\hline Uric acid & $1.87 \pm$ & $3.48 \pm$ & $2.63 \pm$ & $3.29 \pm$ & $2.79 \pm$ \\
\hline$(\mathrm{mg} / \mathrm{dl})$ & $0.091^{\mathrm{c}}$ & $0.295^{\text {a }}$ & $0.389^{b}$ & $0.126 \mathrm{ab}$ & $0.133 \mathrm{ab}$ \\
\hline Creatinine & 0.59 & 12.24 & 0.953 & 1.027 & 0.880 \\
\hline$(\mathrm{mg} / \mathrm{dl})$ & $\pm 0.25^{\mathrm{b}}$ & $\pm 0.343^{a}$ & $\pm 0.018^{\mathrm{b}}$ & $\pm 0.027 \mathrm{~b}$ & $\pm 0.055^{\mathrm{b}}$ \\
\hline
\end{tabular}

The same letter in the same row is not significantly different at $\mathrm{P}<0.05$.

\section{DISCUSSION}

Ammonia toxicity depends on the concentration of (NH3). Fish bronchial membranes are relatively permeable to $\mathrm{NH}_{3}$, but not to $\mathrm{NH}_{4}{ }^{+}$, due to its molecular size. When dissolved in water, ionized and unionized forms of ammonia are in equilibrium, which is affected by water $\mathrm{pH}$, temperature and salinity. High levels of ammonia cause stress and produce harmful physiological response such as osmoregulatory disturbances, kidneys and branchial epithelium damages, retarded growth (Meade, 1989; Soderberg, 1994), and inefficient immune response (Pinto et al., 2007).

Findings of the present study showed that greater weight and feed conversation ratio were achieved when the fish was exposed to zeolite treatment prior to high ammonia concentration exposure. Moreover, comparing the growth of fish in T3 and T5 to T1, T2, and T4 demonstrated that reduction because of the ammonia toxicity, increasing zeolite improved the growth of fish. Evidently, several investigators reported similar results. Frances $\boldsymbol{e t}$ al. (2000) reported a decrease in body weight of silver perch as a consequence 
to elevated ammonia in water. Also, Sakala and Musuka (2014) deduced a toxic effect of increased ammonia on tilapia growth rate. The loss of weight in ammonia treatment is more likely due to the inhibition of the fish appetite leading to significant reduction of feed intake and disturbance in metabolism. Rabiatul et al (2019) showed that ammonia, nitrite, and nitrate levels in water were significantly reduced in treated water with $15 \mathrm{~g}$ zeolite /l compared with the control. It is noted that current results coincide with those of Yoon et al (2015) who reported that ammonia is a common aquatic pollutant and is toxic to fish. The main nitrogenous compound excreted by fish is also ammonia, which may reach toxic concentrations in high-density fish culture, reducing growth and productivity. Acute ammonia impairment to the oxygen-carrying capacity of the blood together (hemoglobin) with other physiological changes can lead to poor feed conversion, poor growth, disease resistance reduction, susceptibility to infections, decrease fecundity, reduction of population sizes and death of fish (EPA, 1998; Jensen, 2003). Similarly, Alkobaby and Hassanien (2007) showed that growth performance of Nile tilapia fingerlings was significantly influenced by ammonia concentration except for the low concentration treatment $(0.098 \mathrm{mg}$ UIA/l $)$ which was reported to be the no observable effect concentration. This value is closed to $0.068 \mathrm{mg}$ UIA/L observed in Nile tilapia fingerlings (El-Shafai $\boldsymbol{e t}$ al., 2004). Typical to the present outcomes, El-Shafai $\boldsymbol{e}$ al . (2004) did not record a reduction in feed intake in ammonia-exposed Nile tilapia fingerlings up to $0.43 \mathrm{mg}$ UIA. Ammonia affects the internal physiology of the fish. Thus, fish may consume feed with no assimilation. However, several studies demonstrated the different reasons of reduction in the growth rate during ammonia exposure. Rasmussen and Korsgaard (1996) and Foss et al. (2003) found that reduced growth was attributed to a decrease in food intake with increasing ammonia concentrations and to reduced food conversion efficiency for juveniles' turbot and spotted wolfish, respectively. Otherwise, food conversion efficiency was unaffected by ambient ammonia concentration.

Changes in the physiological state often reflect alteration of hematologic and blood biochemical values. Clinical chemical analysis is a fundamental tool to diagnose and predict the outcome of diseases and monitor the effects of therapeutic, nutritional and environmental management in human and veterinary medicine. The Ammonia is a production limiting factor in the aquaculture media affecting fish production. Hematological parameters revealed increases $(\mathrm{P}<0.05)$ in both fish exposed to stressors. There were significant decreases $(\mathrm{P}<0.05)$ in red blood cell, hematocrit value and hemoglobin concentration in both males and females of Nile Tilapia after exposure to ammonia toxicity (Zeitoun, et al., 2016). Data given in the present study showed significant decrease in the red blood cell counts (RBCs), hemoglobin $(\mathrm{Hb})$ and hematocrit $(\mathrm{Ht})$ in the Nile tilapia exposed to the ammonia toxicity, the effects were dose-dependent. The decreases in RBCs, $\mathrm{Hb}$ and $\mathrm{Ht}$ were the most common effects usually expected in all animals exposed to chemical and toxicological metabolites in which the hemopoietic 
tissues are the target organs of their effect. The most toxic substances including ammonia, suppress the processes of erythropoiesis and $\mathrm{Hb}$ synthesis. Also, the decrease in the $\mathrm{RBCs}, \mathrm{Hb}$ and $\mathrm{Ht}$ may be due to the elimination of the RBCs from the circulation as a result of butataf-induced extravasations of blood (Mousa, 2004). These results are in agreement with those of Shalaby et al. (2006a), who indicated that the reduction of those blood parameters in Blue tilapia "Oreochromis aureus", at sublethal levels of chromium, might be due to the destruction of mature RBCs and the inhibition of erythrocyte productions due to reduction of hemosynthesis affected by pollutants. The obtained results revealed that toxicated fish were recovered with the addition of zeolite, whereas the RBCs, $\mathrm{Hb}$ and $\mathrm{Ht}$ in fish exposed to low and high dose of ammonia with zeolite were similar to those of the control fish.

Blood chemistry could be an important physiological and toxicological indicator widely used in the evaluation of nutritional status, health status, and the capacity for adaptation to the external environment in fish (shalaby, 2001; Shalaby et al., 2006 a and b; Gingerich et al., 2010; shalaby, et al.,2017; shalaby et al., 2018 and shalaby, et al., 2019).

The quantitative determination of the total protein in plasma, muscle and liver reflects the liver capacity of protein synthesis, and denotes the osmolality of the blood and the renal impairments. Hence, it has proved to be a valuable factor in the diagnosis of toxicity in fish. In the present study, the total plasma protein level decreased significantly, and the effect was dose dependent. This decrease might be attributed to several pathological processes including plasma dissolution, renal damage and protein elimination in the urine, a decrease in liver protein synthesis, alteration in hepatic blood flow and/ or hemorrhage into the peritoneal cavity and intestine (Salah El-Deen et al., 1996). In addition, Mousa and Khattab (2003) stated that the plasma protein and liver protein levels decreased significantly in ochratoxin poisoned fish. The decrease in plasma and tissue protein may occur due to the increase of protein breakdown as a result of stimulated corticosteroid hormones to provide amino acids and enhance the breakdown of proteins and gluconeogenesis providing glucose to compensate the increase in energy demands under stressful condition. These results agree with those of Shalaby (2007) who found a significant decrease in plasma protein level in the in Nile tilapia after toxication with cadmium, Moreover, addition of EDTA in rearing water enhanced health and improved the level of plasma protein asin the control group.

Blood glucose appeared to be sensitive reliable indicator of environmental stress in fish. In the present study, plasma glucose concentration was highly increased in fish poisoned by ammonium chloride (18 or $1.8 \mathrm{mg}$ of $\mathrm{NH}_{4} \mathrm{Cl} / \mathrm{l}$ ). It is clear that ammonias, as shown by the elevated blood glucose level, represented a source of stress on fish. Ammonia induced hyperglycemia was observed in Nile tilapia exposed to different concentrations of $\mathrm{NH}_{4} \mathrm{Cl}$ recorded highly significant increases $(\mathrm{P}<0.05)$. The effect of ammonia is known to increase the levels of catecholamines, activating glycogenolysis 
and glyconeogenesis with a net result of increasing plasma glucose levels. These results confirm the corticosteroid response to high ammonia observed by Tomasso et al. (1981). Soengas et al. (1996) suggested that hyperglycemia occurred in Atlantic salmon (Salmo salar) after toxicity with cadmium. This may be due to the decrease in serum insulin required to control glucose level either through a reduction in the rate of its production or effectiveness of the available insulin. This could be attributed to alteration in the rate and degree of digestion, absorption and utilization of glucose due to the exposure to ammonia or environmental pollutants, i.e. impaired carbohydrate metabolism due to exposure to the ammonia. However, the reduction of the glucose concentration in plasma of fish along with zeolite is due to the removal of ammonia by zeolite.

ALT and ALP are present mainly in cardio myocytes and hepatocytes of fish, respectively, and are necessary for protein metabolism. Damaged or increased permeability of liver and myocardial cells leads to increased levels of AST and ALT, resulting in elevated blood transaminase activity. Therefore, the welfare of fish can be monitored by detecting the activities of AST and ALT (Wang et al., 2012). In this study, post ammonia exposure, plasmatic glucose, lipid profile (total lipids, cholesterol, triglyceride and HDL), ALP, ALT, uric acid and creatinine concentration increased significantly in fish exposed to two doses of ammonium chloride (18 and $1.8 \mathrm{mg}$ $\left.\mathrm{NH}_{4} \mathrm{Cl} / \mathrm{l}\right)$. The results showed that ALT and ALP activities were significantly high in fish group toxicities with doses of ammonia in rearing water compared to the control group. These results might appear because ammonia toxicity induced several pathological processes in different fish organs (yoon $\boldsymbol{e t}$ al., 2015). The previous authors noted that histopathological changes detected in the gills of Nile tilapia after exposure to ammonia toxicity over this period included hypertrophy and fusion and of the secondary lamella. Activities of plasma ALT, ALP, total lipids, cholesterol, Triglyceride, HDL, uric acid and creatinine were significantly lower in fish exposed to low dose of ammonia with $6 \mathrm{~g}$ of zeolite/l as control group. These results suggest that the combination of ammonia and zeolite lead to a decrease in all parameters compared with treated group with ammonium only. Zeolite is cheaper with no side effect, and is more suitable than EDTA, NTA and hence, it may be considered as the best chemical agents to remove toxic elements from polluted environment (James \& Sampath, 1999).

Creatinine and uric acid showed significant increase in fish exposed to different doses of ammonium chloride. These results may be due to the action of ammonia on glomeruli filtration (yoon et al., 2015) and/or it may cause pathological changes to the kidney resulting in dysfunction. Addition of $6 \mathrm{gm}$ zeolite/l to ammonia afforded significant change in sub lethal concentrations $\left(1.8 \mathrm{mg} \mathrm{NH}_{4} \mathrm{Cl} / \mathrm{l}\right)$ as compared to control group. Also, in the combination of zeolite to ammonium chloride shows a non significant change in urea level as compared to control group but less intense as compared with ammonium only. 
Regarding ALT, ALP, uric acid, and creatinine concentrations, it is know that ALT and ALP are frequently used in the diagnosis of damage caused by pollutants in various tissues such as liver, muscle, and gills (Coppo et al., 2003; Chen et al., 2004) and uric acid and creatinine are traditional screening indices for kidney function and renal structural integrity. Therefore, the elevated ALT, ALP, uric acid, and creatinine concentrations in ammonia $\mathrm{NH}_{4} \mathrm{Cl}$ exposed fish are indicative to liver and kidney dysfunction, which led to the leakage of these molecules from the specific organs into the blood stream. Metwally and Wafeek (2014) detected blood glucose, lactic acid and pyruvic acid in Nile tilapia after exposure to ammonia toxicity reporting similar results of the present study.

James and Sampath (1999) reported that zeolite improved feed conversion ratio, kept animals healthy and reduced the cadmium bioaccumulation. They concluded that zeolite addition, with concentrations $0.5,2.0$ and $4.0 \mathrm{~g} / \mathrm{l}$ in water allowed reduction of metal bioaccumulation in gills when treated with $5 \mathrm{gm} / \mathrm{l}$ z. James and Sampath (1999) noticed that zeolite addition reduces $\mathrm{Cd}$ accumulation. They explained that $\mathrm{Cd}$ and $\mathrm{Z}$ could interact in the aqueous medium as follows: Zeolite has extra frame work ions $\mathrm{Na}$, and frame work ions ( $\mathrm{Al}$ and $\mathrm{Si}$ ), which are easily negligible. It is possible that $\mathrm{Cd}$ ions bind $\mathrm{Na}$ extra frame work ions with zeolite, and this $\mathrm{Cd}$ would be immobilized so that $\mathrm{Cd}$ would be reduced. The zeolite administration afforded significant ameliorative effects on nearly all studied parameters.

Finally, the present study suggests that the level of zeolite $(6 \mathrm{~g} / \mathrm{l})$ used in this investigation enhances fish tolerance to environmental stress and reduces ammonia toxicity.

\section{REFERENCES}

Alkobaby, A. I. and Hassanien , H. A. (2007). Acute and chronic ammonia toxicity to Nile tilapia (Oreochromius niloticus ) fingerlings. Egy. J. of Aqutic Research. 33(1): 455-465.

Avnimelech, Y. and Ritvo, G. (2003). Shrimp and fishpond soils: processes and management. Aquaculture, 220: 549-567.

AOAC (1990). (Association of Official Analytical Chemists). The Official Methods of Analyses Association of Official Analytical Chemists International. 15th edition, Arlington, VA, 2220, USA. 213 pp.

APHA (American Public Health Association) (2000). Standard Methods for the Examination of Water and Wastewater (20th edition). Washington, D.C, $301 \mathrm{pp}$.

Boyd, C. E. (1984). Water Quality in Warm water Fishponds. Auburn University Agriculture Experimental Station, Auburn, Alabama, USA, 245 pp. 
Boyd, C.E. and Tucker, C.S. (1998). Pond Aquaculture Water Quality Management. Kluwer Academic Publishers, Boston, MA, USA. 328pp.

Britton, C.J. (1963). Disorders of the Blood. 9th Ed. I. A. Churchill, Ld. London. 189 pp.

Chen, C. Y.; Wooster, G. A. and Bowser, P. R. (2004). Comparative blood chemistry and histopathology of tilapia infected with Vibrio vulnificus or Streptococcus iniae or exposed to carbon tetrachloride, gentamicin, or copper sulfate. Aquaculture, 239: 421-443.

Coppo, J.A.; Mussart, N.B. and Fioranelli, S.A. ( 2003). Physiological variation of enzymatic activities in blood of bullfrog, Rana catesbeiana (Shaw, 1802). Revista Veterinaria, 12: 22-27.

Dacie, J.V, and Lewis, S.M. (1984). “ Practical Haematology” P22 $6^{\text {th }}$ ed Churchill Living Stone. London. Mellbourne and Newyork, 22pp.

Duncan, D. B. (1955). Multiple range and multiple (F) test. Biometrics, 11: 1- 42.

El-Gendy, M., Gouda, A., and Shehab El-Din, M. (2015). Effect of zeolite on feeding rates and growth performance for Nile tilapia (Oreochromis niloticus). International Journal of Scientific Research in Agricultural Sciences, 2: 18-24

El-Shafai, S.A.; El-Gohary, F.A.; Nasr, F.A.; Peter van der steen, N. and Gijzen, H.J. (2004). Chronic ammonia toxicity to duckweed-fed tilapia (Oreochromis niloticus), Aquaculture, 232: 117-127.

El-Sayed, A. F. M. (2006). Tilapia Culture. Edited by CABI publishing, Cambridge USA: 274 pp.

EPA (United States Environmental Protection Agency) (1998). Update of Ambient Water Quality Criteria for Ammonia, USA. United States Environmental Protection Agency, 822-R-98-008.52-107.

Farhangi, M. and Rostami-Charati, F. (2012). Increasing of survival rate to Acipenser persicus by added clinoptilolite zeolite in acute toxicity test of ammonia. Aquaculture, Aquarium, Conservation \& Legislation International Journal of the Bioflux Society, 5: 18-2.

FAO (2014). The State of World Fisheries and Aquaculture 2014. Arabic Edition, Page: 24, Roma.

FAO (2019). The State of World Fisheries and Aquaculture 2019. Arabic Edition, Page: 30 Roma

Foss, A.; Evensen, T.H.; Vollen, T. and Qiestad, V. (2003). Effects of chronic am exposure on growth and food conversion efficiency in juvenile spotted wolfish, Aquaculture, 228: 215-224.

Frances, J., B.F. Nowak, L.A. and Geoff. L. (2000). Effects of ammonia on juvenile silver perch (Bidyanus bidyanus). Aquaculture, 183: 95-103.

GAFRD (General Authority for Fish Resources Development) (2012). Fish statistics year book. Egyptian Ministry of Agriculture. 89 pp. 
Ghasemi, Z., Sourinejad, I., Kazemian, H., and Rohani, S. (2016). Application of zeolites in aquaculture industry: a review. Reviews in Aquaculture, $212 \mathrm{pp}$.

Gingerich, A.J., Philipp, D.P. and Suski, C.D. (2010). Effects of nutritional status on metabolic rate, exercise and recovery in a freshwater fish. J. Comp. Physiol. B. 180: 371-384.

James, R. and Sampath, K. (1999). Effect of zeolite on the reduction of cadmium toxicity in water and a freshwater fish, Oreochromis mossambicus. Bulletin of nvironmental Contamination and Toxicology, 62(2): 222-

Jauncey, K. and Rose, B. (1982). A Guide to tilapia feeds and feeding, institute of aquaculture. J. Fish. Biol., 21: 533-545.

Jensen, F.B. (2003). Nitrite disrupts multiple physiological functions in aquatic animals. Comparative Biochemistry and Physiology, 135: 9-24.

Joseph, A.; Knight, M.; Anderson, S.; James, M and Rawie, H. (1972). Chemical basis of the sulfophospho-vanillin reaction for estimating total serum lipid. Clin. Chem., 18(3): 198-201

Lowther, A. (2005). Highlights from the FAO database on aquaculture production statistics. FAO Aquaculture Newsletter, 33: 22-24

Meade, J.W. (1989). Allowable ammonia in fish culture. Progress Fish Culture, 47: 135-145.

Metwally, M. and Wafeek, M. (2014). Effect of Ammonia Toxicity on Carbohydrate Metabolism In Nile Tilapia (Oreochromis niloticus)., World Journal of Fish and Marine Sciences., 6(3): 252-261,

Morrison, J.K. and Piper, R.G. (1988). The effect of reused water on Atlantic salmon. Progressive Fish Culturist 50: 110-112. Aceh Journal of Animal Science (2016) 1(1): 21-28 DOI: 10.13170/ajas.1.1.4077.

Mousa, M. A. (2004). Toxicological studies on the effect of machete herbicide on some fish species. Egypt. J. Appl. Sci., 19(5): 1-11

Mousa, M. A. and Khattab, Y. A. (2003). The counteracting effect of vitamin C (Lascorbic acid) on the physiological perturbations induced by ochratoxin intoxication in the African catfish (Clarias gariepinus). J. Egypt. Acad. Environ. Develop., (D. Environmental Studies), 4(1): 117-128.

Mustapha, M. K.; Akinware, B. F.; Faseyi, C. A. and Alade, A. A. (2014). Comparative effect of local and foreign commercial feeds on the growth performance and survival of Clarias gariepinus juveniles. J. Fish. 2(2): 106-112.

Páez-Osuna, F. (2001). The environmental impact of shrimp aquaculture: a global perspective.Mar. Pollut. Bull. 112, 229-231. https://doi.org/10.1016/S02697491(00) 00111-1.

Pinto, C.; Aragão, C.; Soares, F. Dinis M.T. and Conceição, L. E. (2007). Growth, stress response and free amino acid levels in Senegalese sole (Solea senegalensis 
Kaup 1858) chronically exposed to exogenous ammonia. Aquaculture Research, 38: 1198-1204.

Rabiatul, A. Meor, M. Z.; Nur, F. I.; Mohamad, F. M. A and Musfiroh, J. (2019). Effect of Zeolite on the Water Quality and Growth Performance of Red Hybrid Tilapia (Oreochromis niloticus). ICASI 2019, July 18-19, Banda Aceh, Indonesia.

Rasmussen, R.S. and Korsgaard, B. (1996). The effect of external ammonia on growth and food utilization of juvenile turbot (Scophthalmus maximus L.), J. Exp. Mar. Biol. Ecol. 205: 35-48.

Reverter, M.; Bontemps, N.; Lecchini, D.; Banaigs, B. and Sasal, P. ( 2014). Use of plant extracts in fish aquaculture as an alternative to chemotherapy: current status and future perspectives. Aquaculture, 433: 50-61.

Reitman, S. and Frankel (1957). Colorimetric determination of glutamic oxaloacetic and glutamic pyruvic transaminases. Am. J. Clin. Pathol., 28: 53-56.

Rodrigues, F. J.; Lima, F. R.; Vale, D. A and Carmo, M. V. (2013). High levels of total ammonia nitrogen as $+\mathrm{NH}$ are stressful and harmful to the growth of Nile 4 tilapia juveniles. Acta Sci. (Biological Sciences) 35(4): 475-481.

Sakala, M. E. and Musuka, G. (2014). The effect of ammonia on growth and survival rate of Tilapia rendalli in quail manured tanks. International Journal of Aquaculture, 4(22): 1-6.

Salah, El-D, M. and Rogeps, W. A. (1996). Changes in total protein and transaminase activities of grass carp exposed to diquat. J. Aquatic Animal Health, 5: 280-286.

Shalaby, A. M. (2001). Protective effect of ascorbic acid against mercury intoxication in Nile tilapia (Oreochromius niloticus). J. Egypt. Acad. Soc. Environ. Develop.(D-Environmental Studies), 2(3): 79-97.

Shalaby, A. M. (2007). Effect of EDTA on toxicity reduction of cadmium in relation to growth, some haematololgical and biochemical profiles of Nile tilapia (Oreochromis niloticus), Journal of Fisheries and Aquatic Science 2(2):100-109.

Shalaby, A. M.; El- Ashram. A. M. and Mesalhy, S. E. (2006a). Reproductive and patho-physiological responses of Nile tilapia" O. aureus" exposed to chromium with or without chelating substances. Egypt. J. Exp. Biol. (Zool.), 2: 195- 205.

Shalaby A. M.; Diab, A.A.; .Hendawy, A. A; Mariam M. A.; Shalaby, G. and Maaly, A.M. (2018). The impact of zeolite against cadmium chloride toxicity in Nile tilapia (Oreochromis niloticus). Abbassa, Int. J. Aqua., 11(2): 335-358.

Shalaby A. M.; Khattab, Y. A. and Abdel-Rahman A. M. (2006b). Effects of garlic (Allium sativum) and chloramphenicol o growth performance, physiological parameters and survival of Nile tilapia (Oreochromis niloticus). J. Venom. Anim. Toxins incl. Trop. Dis., 12(2): 172-201. 
Shalaby, A.M.; Said, A. A.; Kairy, M. H. and Ismail, H. T. (2017). Biochemical studies in Oreochromius niloticus exposed to lead acetate and treated by carob or fig ether extracts. Egypt. J. Aquac., 7(1):1-14.

Shalaby, A. M.; Shoker, E. A.; Khames, M. K.; Khames, D. K.; Zenahm and Radwan, M. E. (2019). Using of yucca schidigera extract (yse) against ammonia toxicity at different stoking density for improvement growth performance and physiological status of Nile tilapia (Oreochromis niloticus)., Abbassa Int. J. Aqua.,12(1):183-206.

Snedecor, G. W. and Cochran, W. G. (1982). Statistical Methods. $6^{\text {th }}$ edition. Iowa State Univ. Press., Amer., IA, USA, pp 593.

Soderberg, R.W. (1994). Flowing water fish culture. CRC Press, Boca Raton, 147.

Soengas, J. L.; Agra-Lago, M. J.; Carballo, B.; Andres, M. D and Veira, J. A. R (1996). Effect of an acute exposure to sublethal concentration of cadmium on liver carbohydrate metabolism of Atlantic salmon (Salmo salar). Bull. Environ . Contam. Toxicol., 57: 625- 631

Trinder, P. (1969). Determination of glucose concentration in the blood. Ann. Clin. Biochem., 6: 24.

Tomasso, J.R.; Davis, K.B and Simco, B. A. (1981). Plasma corticosteroid dynamics in channel catfish (Ictalurus punctatus) exposed to ammonia and nitrite. Can. J. Fish. Aquat. Sci., 38: 1106-1112.

Van Kampen, E.J. (1961). Determination of haemoglobin. Clin. Chem. Acta, 5: 719720

Wang, H. F.; Wang, J. L.; Wang, C.; Zhang, W. M.; Liu, J. X. and Dai, B. (2012). Effect of bamboo vinegar as an antibiotic alternative on growth performance and fecal bacterial communities of weaned piglets. Livest. Sci., 144:173-180.

Wootton, L. D. P. (1964). Micro -analysis in Medical Biochemistry in Micrometer. Churchill, London. Basel. Kager., $4^{\text {th }}$ Ed., p:264

Yoon, G.; Al-Saadi, N and Ambuali, A. (2015). Gill histology of Nile tilapia Oreochromis niloticus following chronic and acute exposure to ammonia. Journal of Agricultural and Marine Sciences. 19(1): 66-72.

Zeitoun, M. M.; EL-Azrak, K. M.; Zaki, M. A.; NematAllah, B. R. and Mehana, E. E. (2016). Effects of ammonia toxicity on growth performance, cortisol, glucose and hematological response of Nile Tilapia (O. niloticus), Aceh Journal of Animal Science., 1(1): 21-28. 


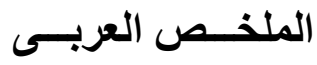

تأثير الزيوليت لاختزال سمية الامونيا وتحسين معدلات النمو والحالة الفسيولوجية فى البطى النيلى (Oreochromis niloticus)

عادل محمد عيسى شلبى1، محمد خلف خميس²، عادل فتحى السعيد 1، امانى عبدالعزيز غريب1، ايمان عطية عبد السميع عبدالحميد3

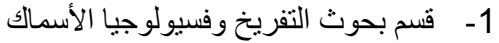

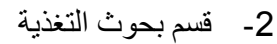

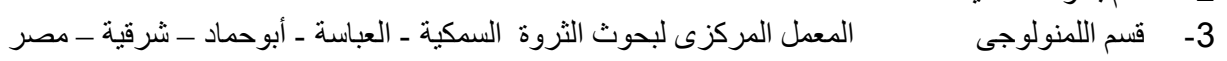

اجرى هذا البحث لدر اسة تأثثر تركيزات مختلفة من كلوريد امونيوم ومعالجته باضافة 6 جرام زيوليت/لتر

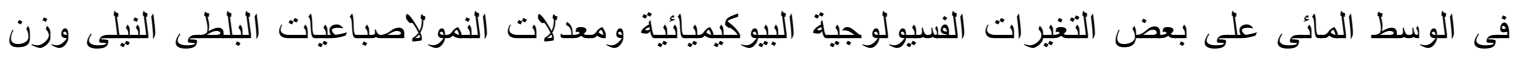

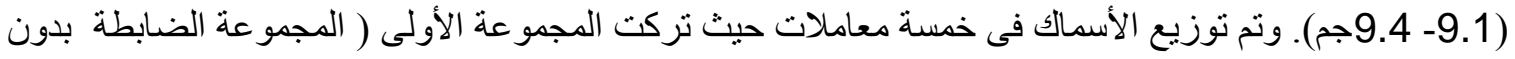

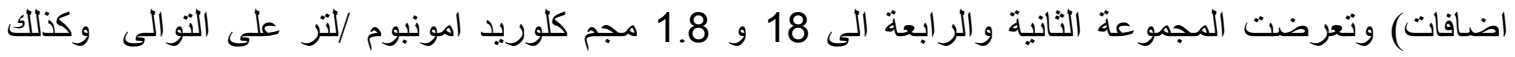

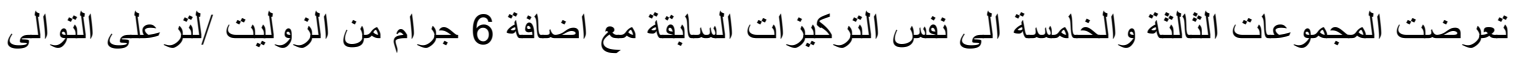

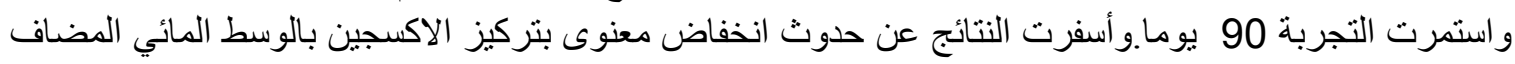

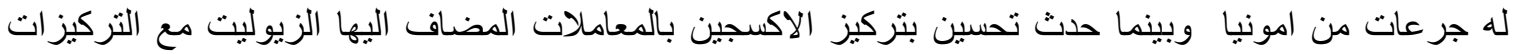

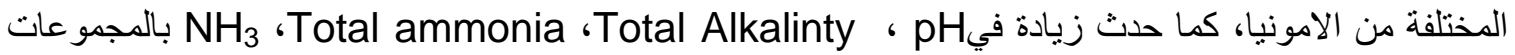

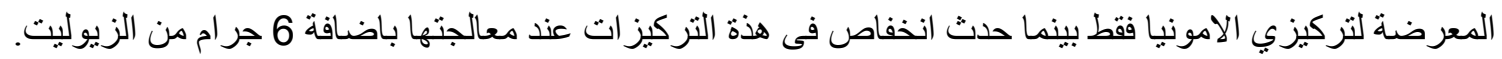

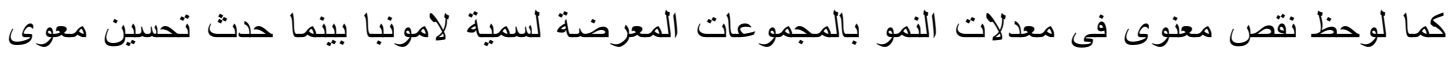

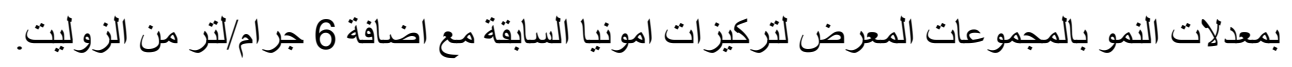

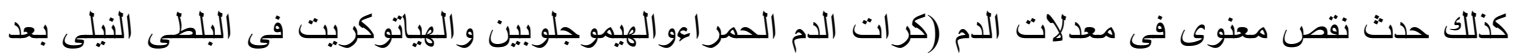

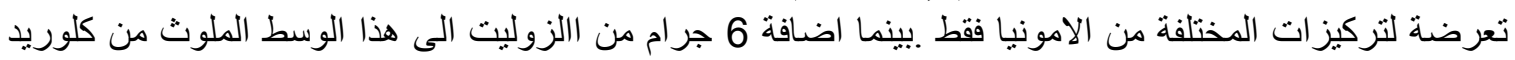

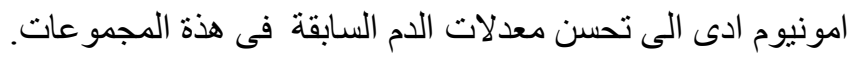

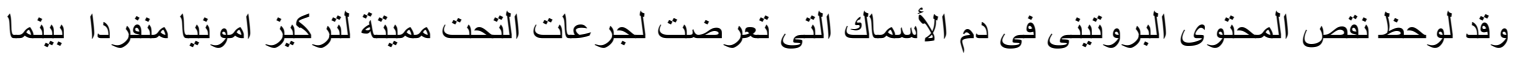

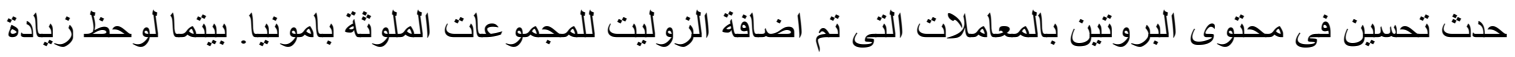

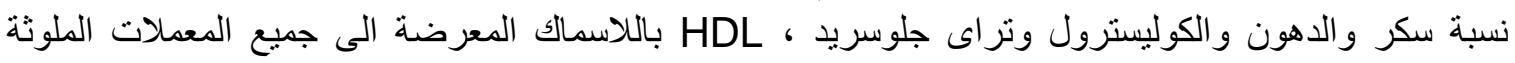

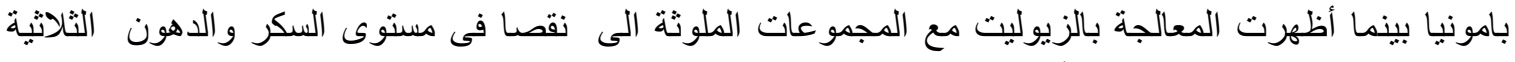

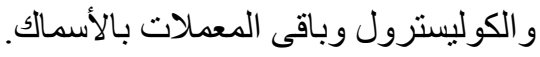

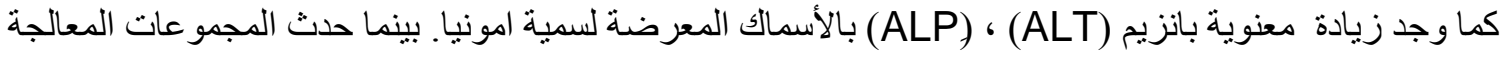

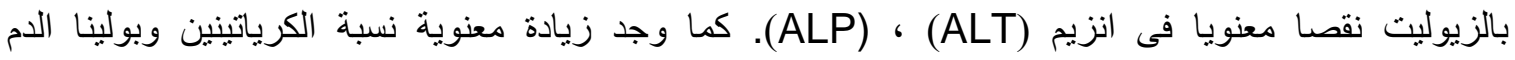

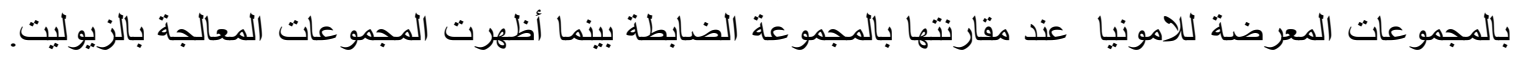

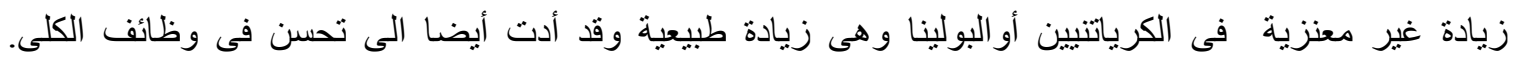

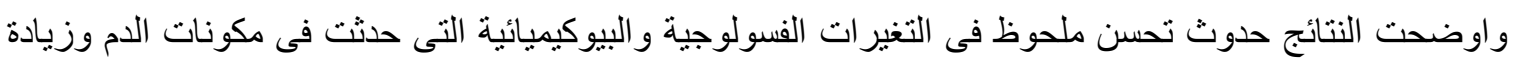

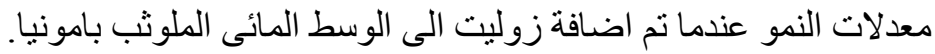

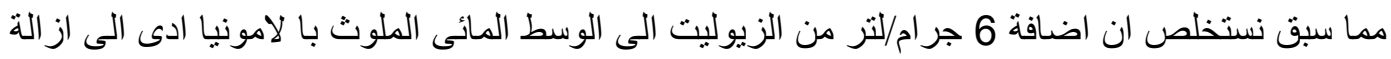

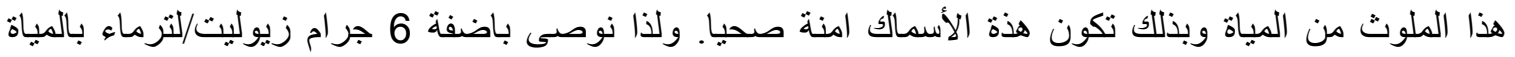

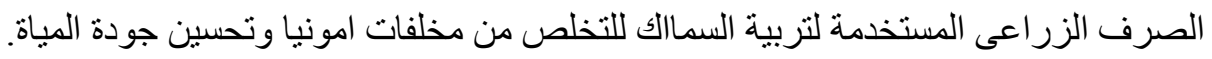

